\title{
Developmental potency of mouse primitive ectoderm cells, embryonic ectoderm cells and primordial germ cells after blastocyst injection
}

\author{
Shen Sanbing \\ Institute of Developmental Biology, Academia Sinica, \\ Beijing, China
}

\begin{abstract}
Developmental potency of primitive and embryonic ectoderm cells from 4.50-day to 6.25-day post-coitum (p.c.) mouse embryos and primordial germ cells from 12.50-day p.c. male genital ridges of fetal mice were studied by direct introducing them into 3.50-day p.c. blastocysts. Sixteen $(61.5 \%)$ overt chimaeras out of $26(50 \%)$ offsprings were obtained after transfer of 52 blastocysts injected with 4.50-day primitive ectoderm cells; four (16.0\%) overt chimaeras were obtained out of 25 (51.0\%) offsprings with 4.75-day primitive ectoderm cells from 49 transferred blastocysts. However, no overt chimaera was obtained with either 5.25-dayor 6.25day embryonic ectoderm cells or 12.50-day male primordial germ cells. GPI analysis of mid-gestation conceptuses developed from injected blastocysts showed that 5.25-day embryonic ectoderm cells could only contributed to yolk sac of conceptus. Results suggested that implantation acts as a trigger for the determination of primitive ectoderm cells, and their developmental potency becomes limited within a short period of time in normal development.
\end{abstract}

Key words:developmental potency, primitive ectoderm cells, embryonic ectoderm cells, primordial germ cells, blastocyst injection, pluripotent stem cell origin.

\section{INTRODUCTION}

Two types of routine pluripotent stem cell lines of embryo origin (tumor-derived embryonal carcinoma (EC) cell lines and embryo-derived stem (ES) cell lines) have been widely used for studying gene expression[1-3] and cell differentiation in early 
embryonic development[4], as both EC[5-9] and ES[10-11]cells could participate in embryogenesis and give rise to adult chimaeras after being introduced into blastocysts. Most of EC cell lines which could participate in embryogenesis following blastocyst injection were from ectopic grafting of 3.50-day blastocysts, 6.50-day or 7.50-day egg cylinders[8]. ES cells were obtained by culture in vitro of inner cell mass in EC cells conditioned medium[12], or normal and delayed blastocysts on feeder layers of fibroblasts[13-14].

Precise relationships between embryonic cells and EC/ES cells are not well understood. It was suggested [15] that all EC cells were derived from germ cells or their precursors. Others suggested that EC cells in embryo-derived teratocarcinomas were derived from embryonic ectoderm, because ECcells were similar to embryonic ectoderm cells in many respects[16-18], and ectopic grafting of embryonic ectoderm might also produced teratoma[19]. Stevens suggested that there were some undifferentiated cells in the embryos, if normal cell-to-cell relationships weredis. rupted, cells might fail to get a message to differentiate and remain undifferentiated, and then transplantable teratocarcinomas could be derived from those undifferentiated cells[20]. If this were the common mechanism of EC cell origin, we should be able to find out those undifferentiated cells by blastocyst injection in embryos of all stages from which teratocarcinomas could be induced.

By using blastocyst injection method, it was demonstrated that primitive endoderm cells from 4.50-day embryo, embryonic endoderm cells, extraembryonic endoderm and ectoderm cells from early postimplantation embryos could only take part in the development of extraembryonic tissues, but not in fetus[21-22]. On the other hand, primitive ectoderm cells from 4.50-day implanting embryo seemed to be totipotent as they could give rise to germ-line chimaeras by the same technique[23-24].

In present paper, overt chimaerism was used as a criterion to study the developmental potency of primitive ectoderm cells (PECs) or embryonic ectoderm cells (EECs) from implanting or implanted embryos, and that of primordial germ cells (PGCs) from 12.50--day male genital ridges, and to try to explain the relationship between embryonic cells and EC/ES cells.

\section{MATERIAL AND METHODS}

\section{Mice}

Mice used in this study were C57BL/6J (black, GPI- ${ }^{\mathrm{b} / \mathrm{b}}$ ) for providing primordial germ cells and embryonic ectoderm cells, ICR (albino, GPI- $1^{\mathrm{a} / \mathrm{a}}$ ) for recipient blastocysts and pseudopregnant fostermothers and vasectomized Kunming mice. All mice were maintained in our own animal rooms equipped with air condition in a lighting regime in which dark period was 7:30 p.m. to 7:30 a.m.. It was assumed that mating occurred at mid-dark, 1:30 a.m..

\section{Recovery of embryos}

All mice for providing embryos were naturally mated. Recipient blastocysts were flushed 
out with Whitten's medium from 3.50-day p.c. uteri of ICR females. The 4.50--day (108h) and 4.75-day (114h) p.c. embryos (Plate I.Figs. 1 and 2) for isolating primitive ectoderm cells were flushed out in the same way from uteri of day 5 (the blug day was recorded as day one) C5713L/6J females at 1:30 p.m. and 7:30 p.m. respectively.

5.25-day (126h) and 6.25-day (150h) p.c. embryos (Plate I,Figs. 3 and 4) were dissected from uteri of day 6 or 7 p.c. C57BL/6J females at 7:30 a.m. with watcbmaker's forceps to release the egg cylinders from investing parietal yolk sac tissues. All embryos were cultured in incu bator containing $5 \% \quad \mathrm{CO}_{2}$ in air at $37^{\circ} \mathrm{C}$ before operation.

\section{Isolation of donor cells}

Primitive ectoderm cells were prepared in the same way as described before, from 4.50day or 4.75-day p.c. implanting embryos[24]. Single embryonic ectoderm cells were isolated from 5.25-day or 6.25-day p.c. egg cylinders by cutting the egg cylinder into two across the embryonic-extra-embryonic junction, incubating the embryonic part in $\mathrm{Ca}^{++}, \mathrm{Mg}^{++}$-free Hank's solution containing $0.25 \%$ Trypsin (Difco $1 / 250$ ) and $0.1 \%$ EDTA at $37^{\circ} \mathrm{C}$ for $5 \mathrm{~min}$, then separating the embryonic part into embryonic cell clump and a monolayer of embryonic endoderm with a micropipette, finally pipetting the embryonic cell clump into singls cells. Isolated single cells were washed in several changes of Whitten's medium contained $10 \%$ calf serum.

Primordial germ cells (Plate I, Fig.6) were isolated from male genital ridges (Plate I, Fig. 5) of 12.50-day p.c. C57BL/6J fetal mice with the method and described by McLaren[22].

\section{Blastocyst injection and embryo transfer}

Blastocyst injection was carried out under Leitz microscope with the aid of Leitz micromanipulators as described before[24]. For 4.50-day or 4.75-day of primitive ectoderm cell, two to four cells were injected into each blastocyst, whereas for 5.25- or 6.25-day embryonicectoderm cell or primordial germ cell, about ten cells were injected per blastocyst. Following l-2h incubation after injection, blastocysts were transferred into uteri of day 3 pseudopregnant ICR females which were mated with vasectomized Kunming White males.

\section{Detection of chimaeras}

Coat color and glucose phosphate isozyme (GPI-1) were used as genetic markers. C57BL/6J mice are black in coat color and pigmented in eyes, GPI-1 locus is b/b; ICR mice are albino in coat color and pink in eyes, GPI-1 locus is a/a. Coat color and pigment in eyes were used to identify the overt chimaeras after offsprings were born. Breeding experiment between chimaera and ICR mice was carried out to show the germ-line chimaerism. GPI analysis were used to detect the chimaerism in internal tissues of overt chimaeras or different parts of midgestation embryos.

\section{RESULTS}

\section{Primitive ectoderm cells (PECs)}

Results of 4.50-day p.c. PEC injection and 4.75-day p.c. PEC injection were summarized in Table 1.52 blastocysts were injected with 4.50-day PECs and trans- 
ferred into 5 pseudopregnant fostermothers. Four became pregnant with $26(50 \%)$ offsprings. Among them, $16(61.5 \%)$ overt chimaeras both in coat and eyes (PlateII, Figs. 7 and 8). 49 blastocysts were injected with 4.75-day PECs, transferred into 6 fostermothers. $25(51.0 \%)$ offsprings were born, only 4 of them were overt chimaeras ( Plate II, Fig. 9), chimaeric rate $16.0 \%$, significantly lower $\left(x^{2}=8.42\right.$, $\mathrm{P}<0.01$ ) than that of 4.50-day PEC injection.

\section{Germ-line chimaerism of overt chimaeras}

Germ-line chimaerism of overt chimaeras was tested by breeding them with ICR mice separately. Results were summarized in Table 2. among 16 overt chimaeras

Table 1. Offsprings obtained after transfer of blastocysts injected with PECs into foster mothers

\begin{tabular}{|c|c|c|c|c|c|c|c|}
\hline $\begin{array}{l}\text { Source of } \\
\text { donor } \\
\text { cells }\end{array}$ & $\begin{array}{l}\text { Foster- } \\
\text { mother } \\
\text { no. }\end{array}$ & $\begin{array}{l}\text { No.of } \\
\text { transferred } \\
\text { blastocysts }\end{array}$ & $\begin{array}{l}\text { No.of } \\
\text { offspring } \\
\text { born }\end{array}$ & $\begin{array}{l}\text { No.of } \\
\text { overt } \\
\text { chimaeras }\end{array}$ & $\begin{array}{l}\text { Sex } \\
\text { type } \\
\text { chin } \\
\mathrm{M}\end{array}$ & $\begin{array}{l}\text { eno- } \\
\text { eras } \\
\text { F }\end{array}$ & $\begin{array}{l}\text { Chimaera } \\
\text { no. }\end{array}$ \\
\hline $\begin{array}{l}\text { 4.50-day } \\
\text { (108h) } \\
\text { PECs }\end{array}$ & $\begin{array}{l}\text { A01 } \\
\text { A02 } \\
\text { A03 } \\
\text { A04] } \\
\text { A05 } \\
\end{array}$ & $\begin{array}{r}10 \\
11 \\
11 \\
7 \\
13\end{array}$ & $\begin{array}{r}7 \\
4 \\
10 \\
5 \\
0 \\
\end{array}$ & $\begin{array}{l}4 \\
2 \\
5 \\
5\end{array}$ & $\begin{array}{l}2 \\
0 \\
2 \\
3\end{array}$ & $\begin{array}{l}2 \\
2 \\
3 \\
2\end{array}$ & \\
\hline & Total & 52 & $26(50.0 \%)$ & $16(61.5 \%)$ & 7 & 9 & Ca.1-16 \\
\hline $\begin{array}{l}\text { 4.75-day } \\
(114 \mathrm{~h}) \\
\text { PECs }\end{array}$ & $\begin{array}{l}\text { B01 } \\
\text { B02 } \\
\text { B03 } \\
\text { B04 } \\
\text { B05 } \\
\text { B06 } \\
\text { Total }\end{array}$ & $\begin{array}{r}13 \\
5 \\
9 \\
9 \\
5 \\
8 \\
49\end{array}$ & $\begin{array}{c}6 \\
3 \\
6 \\
8 \\
2 \\
0 \\
25(51.0 \%)\end{array}$ & $\begin{array}{l}0 \\
1 \\
1 \\
2 \\
0\end{array}$ & 1 & $\begin{array}{l}1 \\
1 \\
1\end{array}$ & $\begin{array}{l}\mathrm{Cb} .2 \\
\mathrm{Cb} .1 \\
\mathrm{Cb} .4 .3\end{array}$ \\
\hline
\end{tabular}

Table 2. Germ-line chimaerism of overt chimaeras by breeding them with ICR mice

\begin{tabular}{|c|c|c|c|c|c|c|}
\hline \multicolumn{2}{|c|}{ Chimaera } & \multirow{2}{*}{$\begin{array}{c}\text { Sex of } \\
\text { ICR mice }\end{array}$} & \multirow{2}{*}{$\begin{array}{c}\text { Litters } \\
\text { born }\end{array}$} & \multirow{2}{*}{$\begin{array}{l}\text { No.of total } \\
\text { offsprings }\end{array}$} & \multicolumn{2}{|c|}{ Coat color of offspring } \\
\hline No. & Sex & & & & Albino & Pigmented \\
\hline Ca.1 & $\mathrm{F}$ & $\mathrm{M}$ & 7 & 95 & 85 & 10 \\
\hline Ca.3 & $\mathrm{F}$ & M & 6 & 54 & 49 & 5 \\
\hline Ca.8 & $\mathrm{F}$ & M & 1 & 8 & 7 & 1 \\
\hline Ca.9 & $\mathrm{F}$ & M & 2 & 8 & 7 & 1 \\
\hline Ca.10 & M & $\mathrm{F}$ & 7 & 75 & 61 & 14 \\
\hline Ca.11 & M & $\mathrm{F}$ & 3 & 20 & 14 & 6 \\
\hline Ca.12 & M & $\mathrm{F}$ & 4 & 37 & 36 & 1 \\
\hline Ca.13 & M & $\mathrm{F}$ & 3 & 20 & 12 & 8 \\
\hline Ca.16 & $\mathrm{M}$ & $\mathrm{F}$ & 6 & 59 & 55 & 4 \\
\hline Ca.1 & $\mathrm{F}$ & M & 1 & 10 & 10 & 0 \\
\hline Ca.2 & $\mathrm{F}$ & M & 2 & 25 & 25 & 0 \\
\hline Ca.3 & $\mathrm{F}$ & M & 1 & 14 & 14 & 0 \\
\hline Ca.4 & M & $\mathrm{F}$ & 3 & 36 & 36 & 0 \\
\hline
\end{tabular}


obtained by 4.50-day (108h) p.c. PEC injection, 9 of them could produced functional gametes derived from injected PECs. However, no functional gametes derived from 4.75-day (114h) p.c. PECs have been observed in four chimaeras (No. Cb. 1-4).

GPI analysis of four chimaeras (No. Cb. 1-4) shows that injected 4.75-day p.c. PECs were present in lung, liver, digestive tube,kidney,blood, heart, muscle, spleen, lens, brain as well as gonad tissue (see Table 3), although functional gametes from injected 4.75-day PECs have not been produced.

Table 3. Distribution of 4.75-day p.c. PECs in four chimaeras (No. Cb. 1-4) analysed by GPI electrophoresis *

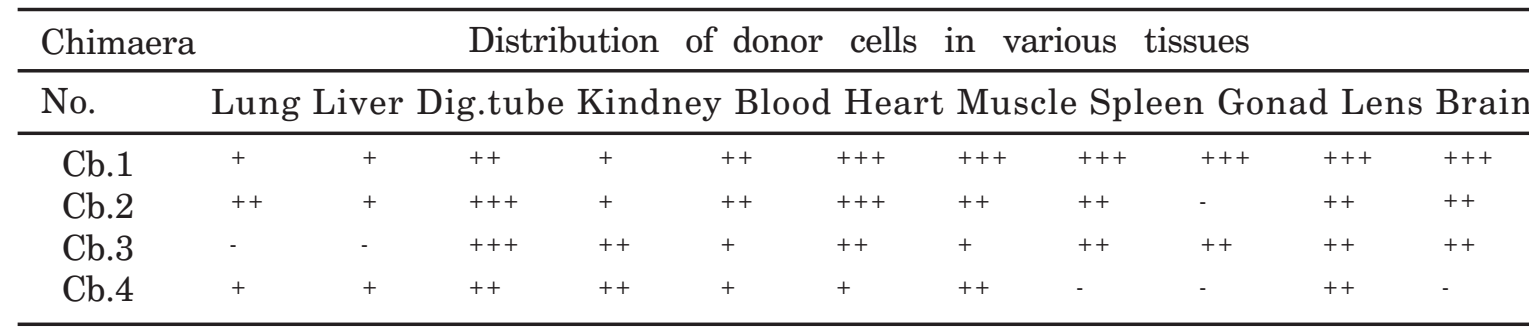

* The proportion of donor cells in tissues was symbolized with +++ , about $50 \%$; ++ , about $30 \%$; + about $10-20 \%$ and - not significant.

\section{Tumors in overt chimaeras}

In sixteen overt chimaeras developed from ICR blastocysts injected with 4.50day primitive ectoderm cells of C57BL/6J mice,one chimaera(No. Ca.5, female) carried a tumor near the vulva under skin at the age of seven months. GPI analysis of tumor cells showed that they originated from ICR cells. A part of tumor was separated in d-Hank's solution containing Trypsin and EDTA, and injected subcutaneously into four female chimaeras at each armpit site of forelimbs. Seven tumors were formed 1.5 months later, and they all died with tumors. Paraffin section of the tumors showed that they were mammary tumors.

In another group of five overt chimaeras made by injecting 4.50-day PECs of 129/SV-ter mice into 3.50-day blastocysts of C57BL/6J mice, two tumors developed in two chimaeras[24].Chim, aera No. 11(female) carried a malignant mammary tumor near the right bindleg at the age of 8.5 months: after its removal, another tumor near the right forelimb was formed one month later. Chimaeras No. 13 (male) carried a tumor at the armpit site of left forelimb at the age of 16 months. They were all derived from C57BL/6J cells tested by GPI analysis.

\section{Embryonic ectoderm cells (EECs)}

$68(66.0 \%)$ offsprings were born after transfer of 103 blastocysts injected with 5.25-day (126h) p.c. EECs, and 57 (58.2\%) offsprings after transfer of 98 blastocysts injected with 6.25-day (150h) p.c. EECs. None of them was overt chimaera. GPI analysis was carried out in mid-gestation for the concegtuses developed from 
blastocysts injected with 5.25-day p.c. EECs. Conceptuses were dissected from the uteri of ICR females between llth and 13th day of gestation, and separated surgically into three parts: fetus, yolk sac and ectoplacental cone. Among 33 conceptuses analysed, injected EECs were only found in yolk sac of four conceptuses (Table 4 ).

Table 4. Distribution of GPI isozyme in chimaeric conceptuses developed in ICR foster mothers from ICR $\left(\mathrm{GPI}-1^{\mathrm{a} / \mathrm{a}}\right)$ blastocysts injected with 5.25-day embryonic ectoderm cells of C57BL/6J(GPI-1 $\left.{ }^{\mathrm{b} / \mathrm{b}}\right)$ mice.

\begin{tabular}{ccccc}
\hline \multirow{2}{*}{ Conceptus No. } & \multicolumn{4}{c}{ GPI. distribution } \\
\cline { 2 - 5 } & Fetus & Yolk & sac & Ectoplacental cone \\
\hline 2 & A & A+B & $5: 1$ & A \\
3 & A & A + B & $5: 1$ & A \\
4 & A & A B & $4: 1$ & A \\
6 & A & A+B & $5: 1$ & A \\
\hline
\end{tabular}

\section{Primordial germ cells (PGCs)}

Male genital ridges (Fig. 5) were dissected from 12.50-day C57BL/6J fetal mice and PGCs (Fig. 6) were released from genital ridges by puncturing with watchmaker's forceps in d-Hank's solution containing Trypsin and EDTA. About ten PGCs were injected into each ICR blastocyst. 45 blastocysts were injected and transferred into uteri of four pseudopregnant fostermothers, and 28 (62.2\%) offsprings were born. None of them was overt chimaera.

\section{DISCUSSION}

Blastocyst is a good developmental vector for carrying pluripotent stem cells and the best way to test the developmental potency of cells, not only EC or ES cells but also embryonic cells, is introducing them into blastocysts to observe their participation in embryogenesis. Results of blastocyst injection of ICM cells, PECs, EECs and PGCs were summarized in Table 5. ICM cells in 3.50-day p.c. blastocyst and PECs in 4.50-or 4.75-day p.c. implanting embryo were totipotent since they

Table 5. Offsprings obtained at blastocysts injection with embryonic

\begin{tabular}{|c|c|c|c|c|}
\hline \multicolumn{2}{|c|}{ Sourece of donor cells } & $\begin{array}{l}\text { No.of injected } \\
\text { and transferred } \\
\text { blastocysts }\end{array}$ & $\begin{array}{l}\text { No.of } \\
\text { offsprings } \\
\text { born }\end{array}$ & $\begin{array}{l}\text { No.of } \\
\text { overt } \\
\text { chimaeras }\end{array}$ \\
\hline 3.50-day & p.c. ICM $^{*}$ & 35 & $28(80.0 \%)$ & $10(35.7 \%)$ \\
\hline 4.50-day & p.c. PECs* & 58 & $31(53.4 \%)$ & $21(67.7 \%$ \\
\hline 4.75-day & p.c. PECs & 49 & $25(51.0 \%)$ & $4(16.0 \%)$ \\
\hline 5.25-day & p.c. EECs & 103 & $68(66.0 \%)$ & 0 \\
\hline 6.25-day & p.c. EECs & 98 & $57(58.2 \%)$ & 0 \\
\hline 12.50-day & p.c. male PGCs & 45 & $28(62.2 \%)$ & 0 \\
\hline
\end{tabular}

* The date including those presented in previous paper (Shen et al., 1988).

+ Among them, three chimaeras carried spontaneous tumors 
could give rise to germ-line chimaeras after being introduced into blastocysts. However, the chimeric rate of 4.75-day PEC injection was significantly lower than that of 4.50-day PEC injection, although morphological changes of embryos between 4.50-day and 4.75-day (Figs. 1,2) was not obvious. No overt chimaera was obtained with either 5.25-or 6.25-day EECs or 12.5-day male PGCs. GPI analysis of midgestation conceptuses developed from injected blastocysts showed that 5.25-day EECs could only take part in yolk sac but not in fetus. Obviously, lower frequency of- overt chimaeras with 4.75-day PECs might reflect less number of pluripotent cells in 4.75-day implanting embryos, and the lack of overt chimaeras with 5.25- or 6.25-day EEC was due to their limited potency. Although 4.75-day PECs were present in all tissues of three germ layer origin, i.e. lung, liver, digestive tube, kidney, blood, heart, muscle, spleen, lens, brain and gonad of overt chimaeras (Table 3) after blastocyst injection, it seemed that 5.25-day EECs were preferentially to colonise extraembryonic mesoderm following blastocyst injection, since they were detected only in yolk sac tissue. It was reasonable to suggest that implantation acts as a trigger for the determination of $\mathrm{PECs}$, resulting in therestriction of their developmental potency at 4.50-day post coitum, and, within a very short peri'od of time after implantation, the capacity for differentiation of all PECs became restricted.

Murine pluripotent stem cell lines, either EC or ES cell lines, could be derived from early embryos (Fig. 1). The origin of ES/EC cells was unknown. Since the most important and useful character of ES/EC cells was their capacity of participating in embryogenesis and giving rise to adult chimaeras after being introduced into blastocysts, we should be able to find out pluripotent cells in intact embryos by blastocyst injection, if ES/EC cells originated from direct proliferation of embryonic cells.

Our results showed that pluripotent cells did exist in embryo through 3.50 to 4.75-day post coitum, since 3.50-day ICM cells, 4.50- or 4.75-day PECs were all able to take part in the development of fetus, but 5.25- and 6.25-day EECs or cells from 12.50-day genital ridge were unable to do so. However, studies on ultrastructure[16-26], histochemistry[17], Forssman antigen and protein synthesis pattern[18] all showed that EC cells were similar to embryonic ectoderm cells of egg cylinder and primordial germ cells of genital ridge, but not to ICM cells. We suggested that EC/ES cells might be derived from embryonic cells (ICM cells, PECs or PGCs) after their alternation through the action of unknown factors in the ectopic environments rather than from direct proliferation of embryonic cells themselves.

It was rather surprising that three overt chimaeras.one $\mathrm{C} 57 \mathrm{BL} / 6 \mathrm{~J} \rightarrow \mathrm{ICR}$ chimaera and two $129 / \mathrm{SV}$-ter $\rightarrow$ C57BL/6J chimaeras, out of 21 chimaeric mice made by blastocyst injection with PECs, had spontaneous tumors, all derived from embryonic 


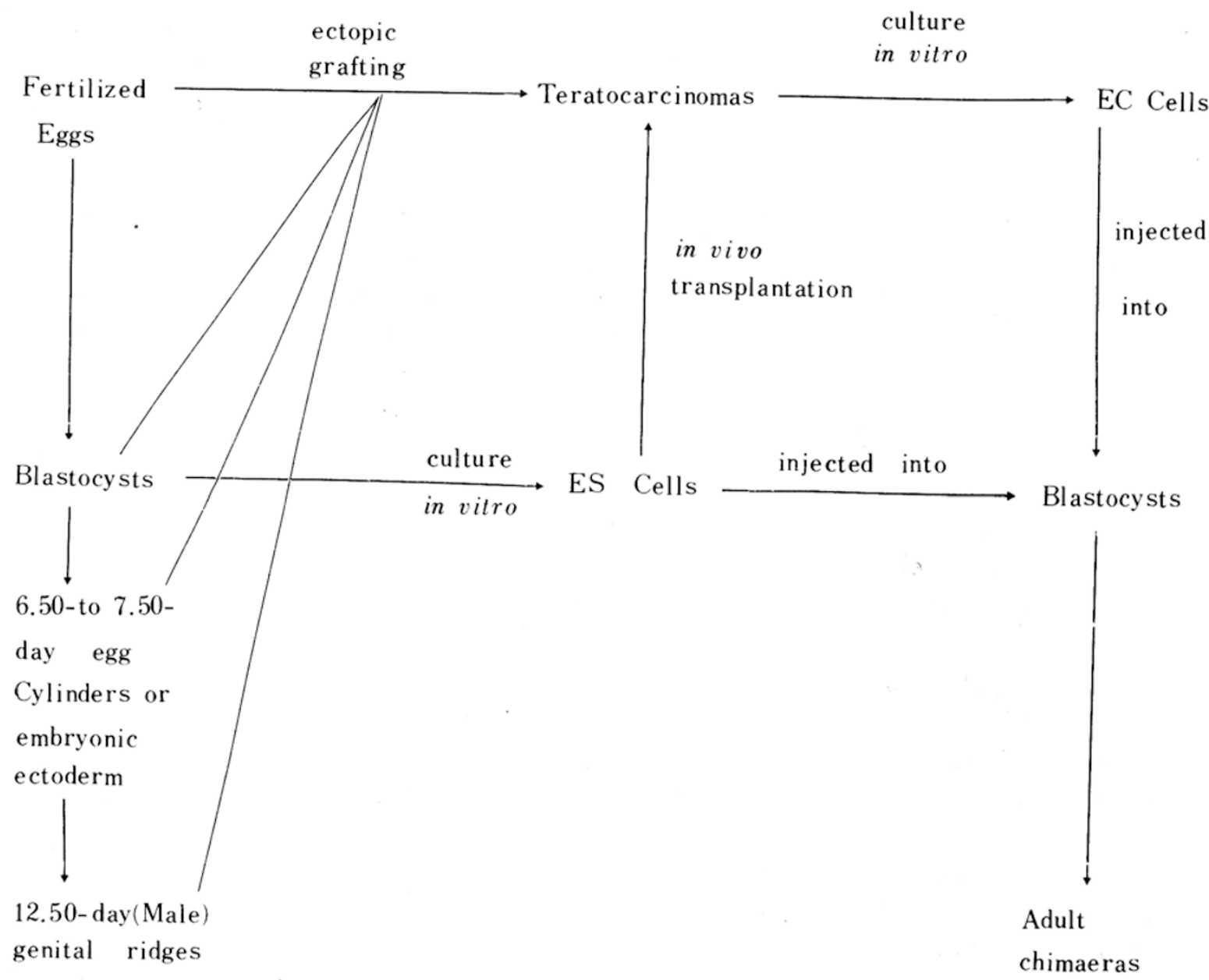

Fig. 1 The relationship between normal embryos and ES/EC cells

cells of recipient strains, ICR or C57BL/6J, by GPI analysis. In normal life span of mice in our laboratory, C57BL/6J or ICR mice never develop tumor spontaneously although 129/SV-ter mice with high frequency of spontaneous teratomas were known. No tumor was reported even in 420 chimearas made by ES cell injection[11-27]. The reason why overt chimaeras derived fromPEC injection developed tumors merits further investigation.

\section{ACKNOWLEDGEMENT}

The project was supported by National Natural Science Foundation of China and Rockfeller Foundation. 
I would like to thank Prof. Lu De-yu and Prof. Tu Miao for guidance and discussion, to thank Mr. Li Jiang-long for photograph services.

\section{REFERENCES}

[1] Stewart L, Vanek M, Wagner EF. Expression of foreign genes from retroviral vectors in mouse teratocarcinoma chimaeras. EMBO J 1985; 4: 3701-3709.

[2] Wagner E, Ruther U, Muller R, Stewart C, Gilboa E, Keller G. Expression of foreign genes in stem cells and mice. In: Costantini F, Jaenisch R, eds. Genetic manipulation of the early mammalian embryo. Cold spring Harbor Laboratory, 1985: 103-113.

[3] Gossler A, Doetschman T, Korn R, Serfling E, Kemler R. Transgenesis by means of blastocysts-derived embryonic stem cell lines. Proc Natl Acad Sci USA 1986; 83: 90659069.

[4] Martin GR. Teratocarcinoma and mammalian embryogenesis. Science 1980; 209:768-776.

[5] Cronmiller C, Mintz B. Karyotypic normalcy and quasinormalcy of developmentally totipotent mouse teratocarcinoma cells. Dev Biol 1978; 67: 464-477.

[6] Illmensee K. Reversion of malignancy and normalized differentiation of teratocarcinoma cells in chimeric mice. In: Russell LB, ed. Genetic mosaics and chimaeras in mammals. New York: Plenum press, 1978: 3-25.

[7] Papaioannou VE, Gardner RL, McBurney MW, Babinet C, Evans MJ. Participation of cultured teratocarcinoma cells in mouse embryogenesis. J Embryol Exp Morph 1978a; 44: 93- 104.

[8] Papaioannou VE. Interactions between mouse embryos and teratocarcinomas. In: Le Douarin N, ed. Cell lineage, stem cells and cell determination. INSERM Symposium No. 10. Elsevier: North Holland Biomedical Press, 1979: 141-155.

[9] Rossant J, MoBurney MW. The developmental Potential of a euploid male teratocarcinoma cell after blastocyst injection. J Embryol Exp Morph 1982; 70: 99-112.

[10] Bradley A, Evans M, Kaufman MH, Robertson EJ. Formation of germ-line chimeras from embryo-derived teratocarcinoma cell lines. Nature 1984; 309: 255-256.

[11] Robertson EJ. Pluripotent stem cell lines as a route into the mouse germ line. Trends in Genetics 1986;2: 9-13.

[12] Martin G. Isolation of a pluripotent cell line from early mouse embryos cultured in medium conditioned by teratocarcinoma stem cells. Proc Natl Acad Sci USA 1981 ;78:76347638.

[13] Axelrod HR, Lader E. A simplified method for obtaining embryonic stem cell lines from blastocysts. In: Silver LM, MartinGR, StricklandS, eds. Teratocarcinoma stem cells. Cold Spring Harbor Laboratory, 1983: 665-670.

[14] Evans M J, Kaufman MH. Establishment in culture of pluripotent cells from mouse embryos. Nature 1981; 292: 154-156.

[15] Papaioannou. VE, Rossant J, Garder RL. Stem cells in early mammalian development. In: Lord BI, Potten CS, Cole R J, eds. Stem cells and tissue homeostasis, British Society for cell Biology Symposium. Cambrridge: Cambridge University Press, 1978b : 49-69 
[16] Solter D, Damjanov I, Skreb N. Ultrastructure of mouse egg cylinder. Zeitschrift fur Anatomie und Entwicklungsgeschichte 1970b; 132: 201-298.

[17] Dmjanov I, Solter D. Ultrastructure of routine teratocarcinomas. In: Damjanov I, Solter D, eds. "Teratoma and differentiation". 1975: 209-220.

[18] Evans M J, Lovell-badge RH, Stern PL, Stinnakre MG. Cell lineages of the mouse embryo and embryonal carcinoma cells: Fossman antigen distribution and patterns of protein synthesis. In: Le Douarin N, ed. Cell lineage,stem cell and cell determination. INSERM Symposium No. 10. Elsevier: North Holland Biomedical Press, 1979:115-129.

[19] Diwan SB, Stevens LC. Development of teratomas from the ectoderm of mouse egg cylinder. J Natl Cancer Inst 1976; 57: 937-942.

[20] Stevens LC. The origin and development of testicular, ovarian and embryo-derived teratomas. In : Silver LM, Martin GR, Strickland S, eds. Teratocarcinoma stem cells. Cold Spring Harbor Laboratory, 1983: 666-670.

[21] Gardner RL. Investigation of cell lineage and differentiation in the extraembryonic endoderm of the mouse embryo. J Embryol Exp Morph 1982; 69: 175-198.

[22] Possant J, Gardner RL, Alexander HL. Investigation of the potency of cells from the postimplantation mouse embryo by blastocyst injection: a preliminary report. J Embryol Exp Morph 1978; 48: 239-247.

[23] Gardner RL, Lyon MF, Evans EP, Burtenshaw MD. Clonal analysis of X chromosome inactivation and the origin of the germ line in mouse embryo. $J$ Embryol Exp Morph 1985; 88: 349-363.

[24] Shen SB, 31J M, Lu DY, Developmental potential of mouse primitive ectoderm cells following blastocyst injection. Acta Biologiae Experimentalis Sinica 1988; 21: 189-199.

[25] McLaren A. Isolation and culture of germ cells from the genital ridge. In: Hogan B, Constantini F, Lacy E, eds. Manipulating the mouse embryo; A laboratory manual. Cold Spring Harbor Laboratory, 1986: 127- 130.

[26] Pierce GB, Beals TF. The ultrastructure of primordial germinal cells of the fetal testes and embryonal carcinoma Cells of mice. Cancer Research 1964; 24: 1553-1567.

[27] Rossant J, Papaionannou VE. The relationship between embryonic, embryonal carcinoma and embryo-derived stem cells. Cell Differentiation 1984; 15: 155-161.

Received 21-10-1988. Accepted 3-1-1989.

Plate I

Fig. 1 Inner cell mass(ICM) in 4.50-day (108h) p.c. implanting blastocyst flushed out from the uterus of C57BL/6J mouse.

Fig. 2 Inner cell mass(ICM) in 4.75-day(114h) p.c. implanting blastocyst.

Fig. 3 Embryonic ectoderm (EE) in 5.25-day (126h) p.c. egg cylinder.

Fig. 4 Embryonic ectoderm (EE) in 6.25-day (150h) p.c. egg cylinder.

Fig. 5 Genital ridge dissected from 12.50-day p.c. fetal mouse.

Fig. 6 Primordial germ cells (arrow) isolated from genital ridge. 

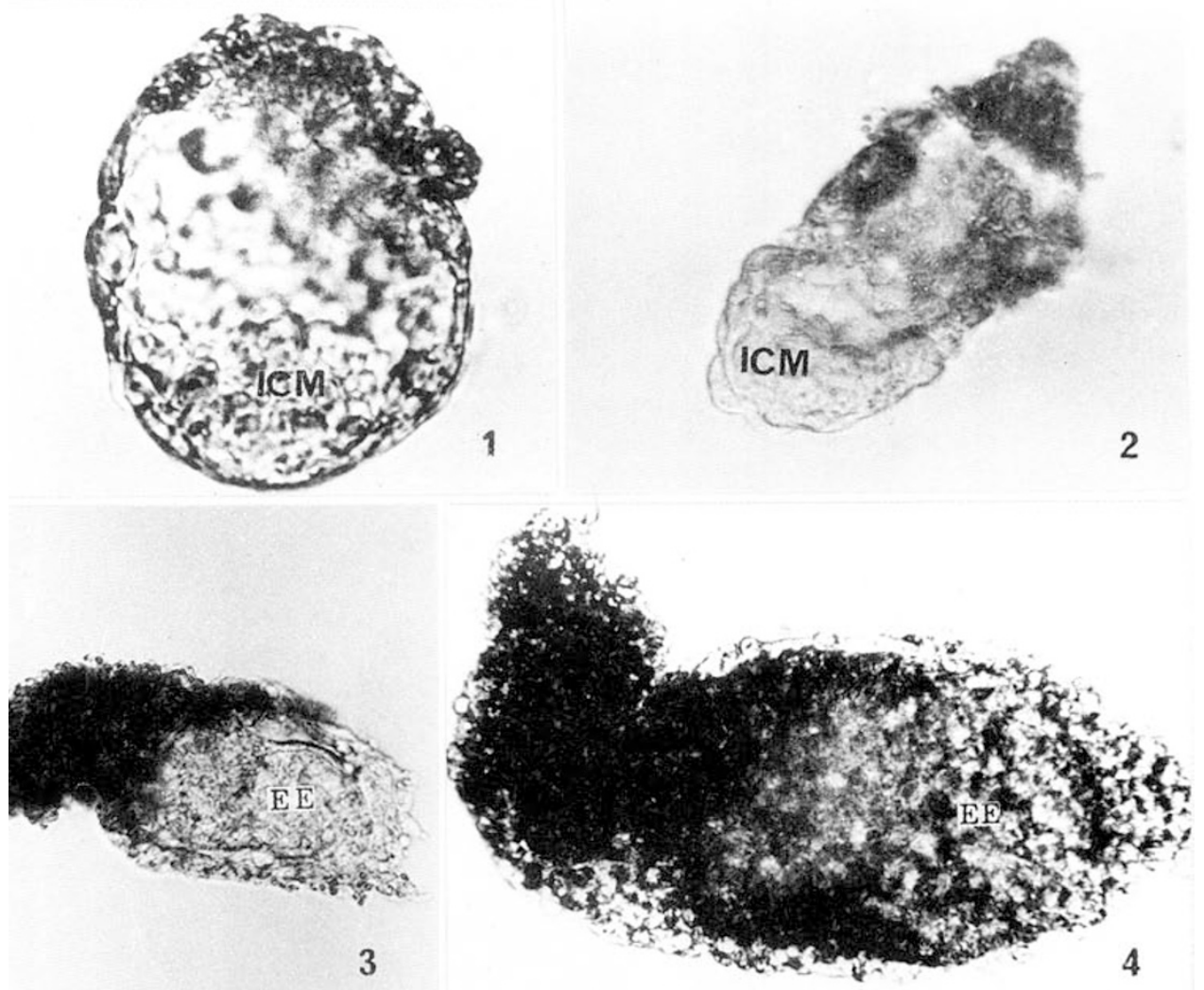

3
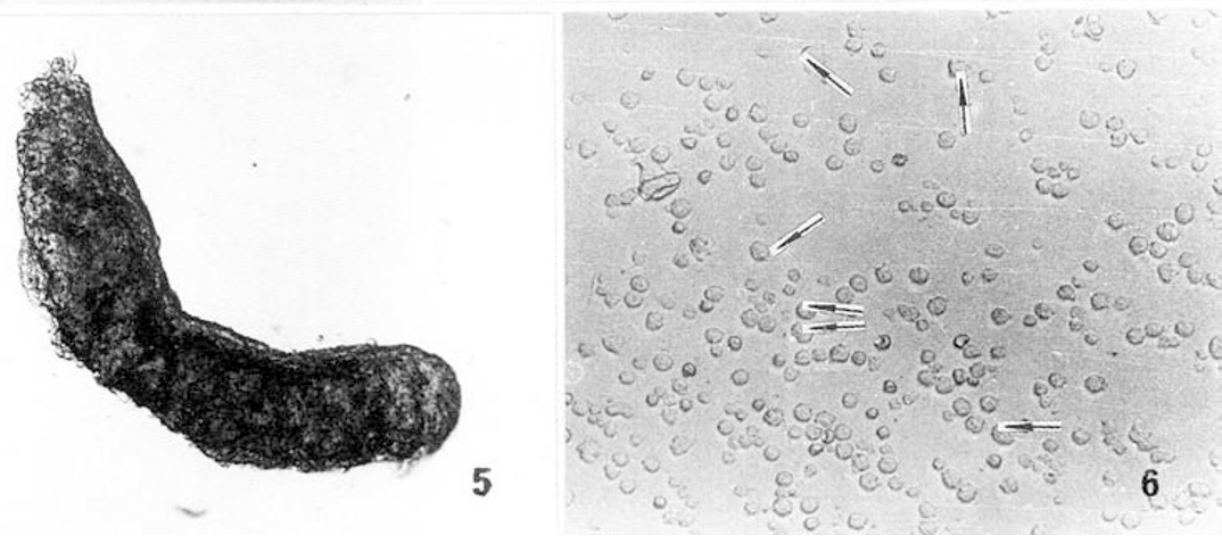
Plate II

Fig. 7 Nine overt chimaeras (female, No. Ca. 1 to 9 from left to right) derived from blastocysts of ICR mice injected with 4.50-day (108h) p.c. primitive ectoderm cells of $\mathrm{C} 57 \mathrm{BL} / 6 \mathrm{~J}$ mice.

Fig. 8 Seven overt chimaeras (male, No. Ca. 10 to 16 from left to right) made by 4.50-day primitive ectoderm cells injection.

Fig. 9 Four overt chimaeras (No. Cb. 1 to 4) made by 4.75-day primitive ectoderm cells injection. 

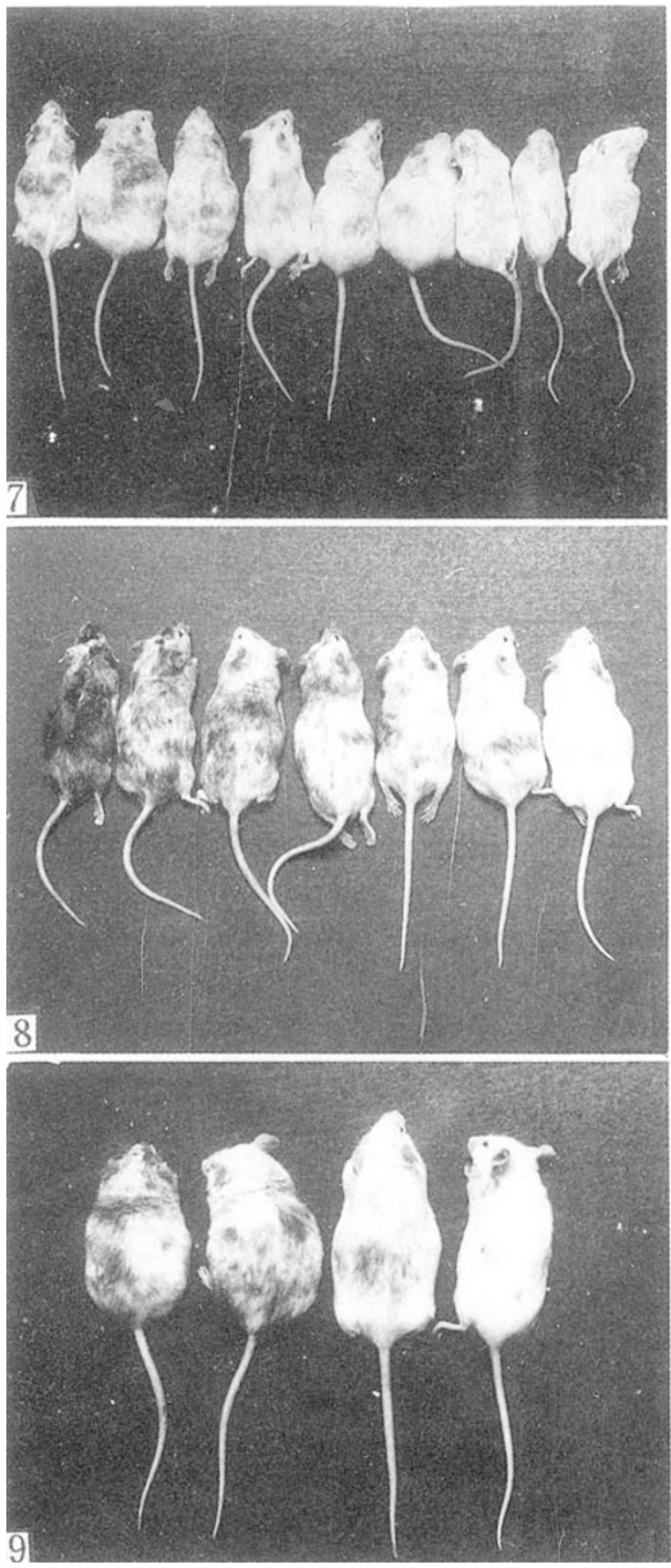